\title{
Editorial: Current Challenges of Smart Cities and Internet of Things
}

\author{
Dagmar Caganova ${ }^{1} \cdot$ Predrag K. Nikolic ${ }^{2} \cdot$ Andy Pusca $^{3} \cdot$ Richard Pospíšil $^{4}$
}

Published online: 23 November 2019

(C) Springer Science+Business Media, LLC, part of Springer Nature 2019

\section{Editorial:}

The special issue Current Challenges of Smart Cities and Internet of Things is dealing with up-to-date topic of globalization challenges in the area of Internet of Things and management. Globalization, rapidly changing technologies and stronger competition put pressure on enterprises to increase innovation rates. Knowledge and intellectual capital are considered to be a source of strategic importance and an engine for innovation in the enterprises. Focus is put on innovation, especially social innovation, mobility to create a platform for sustainable solutions of smart city agenda and other related thematic areas in global multicultural managerial environment.

This special issue features six high quality papers. The first paper "Decentralized Networks: The Future Internet" deals with up to date topic blockchain technology as a pillar and leading concept within decentralized networks. Blockchain technology offers solutions to increase security, verifiability and transparency concerns into order to create cultivating, shared and trusted digital environment. The technology can be used in industries where direct information flow and network security are priority concerns mostly in areas as logistics value chains, quality control in the manufacturing stream, and transparency in maintenance model ranging from simple to sophisticated equipment.

In the second paper "Intellectual Capital as a Key Factor in the Automotive Industry", the authors of the paper consider intellectual capital to be the key asset of an enterprise in today's dynamically developing, knowledge-intensive and

Dagmar Caganova

dagmar.caganova@gmail.com

1 Institute of Industrial Engineering and Management, Faculty of Materials Science and Technology in Trnava, Slovak University of Technology in Bratislava, Bratislava, Slovakia

2 Cheung Kong School of Art and Design, Shantou University, Shantou, China

3 Danubius University, Galați, Romania

4 Faculty of Business and Economics, Mendelu University, Brno, Czech Republic informative environment. The aim of the paper is to point out the relationship between intellectual capital and innovations in the automotive industry, on the example of Volkswagen Slovakia, a.s.

The third paper "The Security Challenges Emerging from the Technological Developments" focuses on the organizations which continually evaluate the security risks their staff are exposed to when performing their job tasks. The paper presents a case study to assess the private and public Portuguese organizations security related practices followed by their staff.

The next paper "Application of Exact Methods in Employee Selection in Accordance with the Age Management Concept" presents the analytic hierarchy process (AHP) as one of the method that can be used in exact decision making. The method was used to solve employee selection in accordance with the Age management concept basis of defined criteria.

The fifth paper "Social Innovations in Smart Cities - Case of Poprad" discusses the concept of smart cities in the context of social innovations. The paper examines smart cities and focuses on Information and Communication Technologies (ICT) as tools for reaching the objective of better and sustainable cities and achieving change in citizens behaviour and improve the quality of life in the city of Poprad in Slovakia.

The main aim of the last paper "The Analysis of the Slovak Citizens' Awareness about the Smart City Concept" is to analyze the awareness of regional cities' citizens in the Slovak Republic about the Smart City concept and to propose the recommendations for improving the implementation of the Smart City elements into cities. The conducted survey showed that despite the efforts of local governments to improve residents' lives through various projects oriented on smart elements, the issue of the lack of citizens' awareness about the Smart City concept remains.

Acknowledgements The guest editors are thankful to the reviewers for their support and effort in reviewing the manuscripts and also thank the Editor-inChief, prof. Imrich Chlamtac for his guidance during the entire process.

Publisher's note Springer Nature remains neutral with regard to jurisdictional claims in published maps and institutional affiliations. 


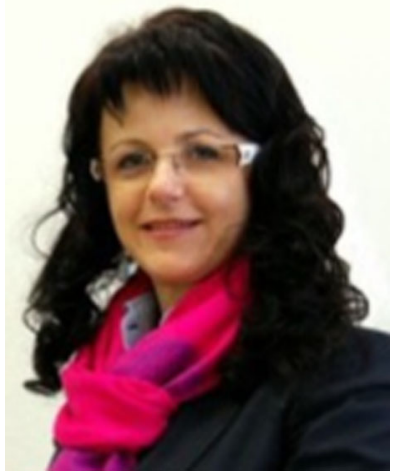

Dagmar Caganova Assoc. prof. in Industrial Engineering, acts as Ambassador / Representative for Foreign Affairs at the Institute of Industrial Engineering and Management, Faculty of Materials Science and Technology in Trnava, the Slovak University of Technology in Bratislava, Slovakia. She is also the co - founder of the European Alliance for Innovation in Slovakia, management committee member of ECOST (European Collaboration in Science and Technology) TN 1301 Sci Generation, the executive committee member in Danubius Academic Consortium (academic network for Integral Innovation), steering committee member of Danube strategy PA 7 Knowledge society- science, research, innovation and ICT for the Slovak Republic. Her professional interests, research topics and international collaborations are mainly focused on Intercultural and Innovation Management, Mobility and Smart Cities, Gender Diversity. She is the member of journal editorial boards, organiser, steering committee member of many domestic and international conferences, acts as tutor on $\mathrm{PhD}$ study programme and has participated in numerous domestic and international projects as team member and as the project head. She is co-editor of Internet of Things, IoT Infrastructures 2014, part 2 and Smart City 360, 2015 published by Springer. To date she has published more than 260 publications, 7 scientific monographs, 33 papers in databases WOS and 35 in databases SCOPUS and has over 300 citations, 117 of them in quotation databases WOS and SCOPUS, h-index in WOS is 6 and SCOPUS h-index 7.

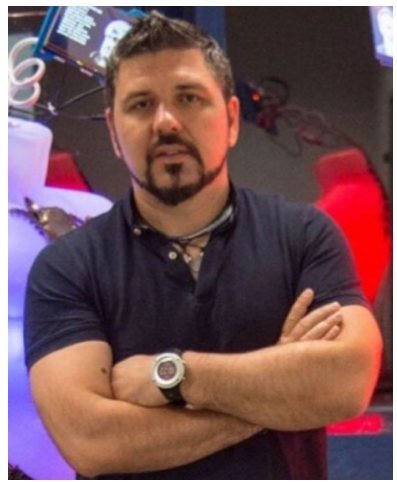

Predrag K. Nikolic is Associate Professor at Cheung Kong School of Art and Design, Shantou University, in China. He is an interactive media designer, international digital media expert and a media artist who holds a $\mathrm{PhD}$ in Digital Media and an MBA. His research focuses on intelligent interfaces, robot creativity, AI aesthetics, machine-made content, design for behavioural changes and smart living environments. He mixes experiential reality, artificial intelligence, and responsive environments to engage an audience in new types of interactive experiences and media perceptions. His design and artworks, such as MIndCatcher, InnerBody, Ciklosol, Before \& Beyond, Vroom, Robosophy Philosophy, Digital Lolipop, Botorikko were exhibited worldwide and presented at the Ars Electronica, SIGGRAPH, SIGGRAPH Asia, Technarte, Singapore Science Center, Hong Kong - Shenzhen Design Biennial, Maison Shanghai, etc. Before joining Shantou University, associate professor Nikolic was Dean of the Faculty of Digital Production in Novi Sad, Visiting Professor at Bergen Academy of Art and Design Norway, Researcher at Aalto University Finland, Global Digital Director at Grey Worldwide, Global Digital Director at J. Walter Thomson Worldwide, Global Head of Digital at Ogilvy Greece, Head of Digital Marketing at Groundlink New York, Consultant at Yahoo and Managing Director at JadePremier London. Predrag K. Nikolic has published numerous research papers in the field of artificial intelligence aesthetics, machine-made content, design for behaviour change, collective creativity, mix-experiential reality, multi-sensory interfaces in smart living environments, interactivity and interface design. He lectures at universities, international conferences, symposium and serves on many conferences committees.

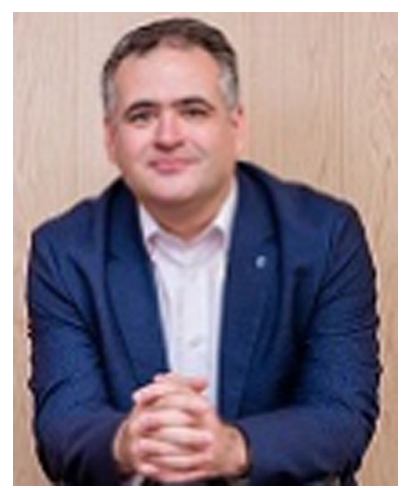

Andy Pusca Assoc. prof. is the rector of Danubius University, Galati Romania. After graduating the Law Faculty within "Danubius" University in 1999, in the same year graduating the Administrative Sciences at the Faculty of Public Administration within the National School of Political and Administrative Studies in Bucharest, he became a teacher.A. Pusca worked as a lawyer, but returned to his first passion, that of being a teacher. He worked with several higher education institutions, teaching at the most prestigious universities in Romania. A. Pusca should mention the extraordinary professional experience that he lived at the National Institute of Magistracy where coordinated the activity of trainee magistrates; then taught Civil Law at the Police Academy and the National School of Political and Public Administration Sciences, Bucharest. As his soul had always remained in Galati, here at "Danubius" University of Galati A. Pusca chose in 2008 to dedicate entire energy and to implement a daring vision for that period in which there was a fierce competition of higher education institutions in Romania. He managed to achieve that through effective strategic measures, by finding alternatives to diversify their offer and to change their approach. And all of this was achieved with the help of a dedicated staff, enthusiastic students and graduates of our university. As a rector, along with his team, he has approached the future of the modern "Danubius" University which has valued the old traditions of higher education, as true strategic visionaries, assuming their new mentality of project management regardless of the field in which they operate: education, research-development-innovation or services. Internationalization, entrepreneurship, open and online are the key terms that will support and direct their determination to fulfill the objectives of "Danubius" University mission, the university who managed to connect the global community through quality, professionalism, enthusiasm and involvement of its people: students, teachers, non-teaching staff, graduates."

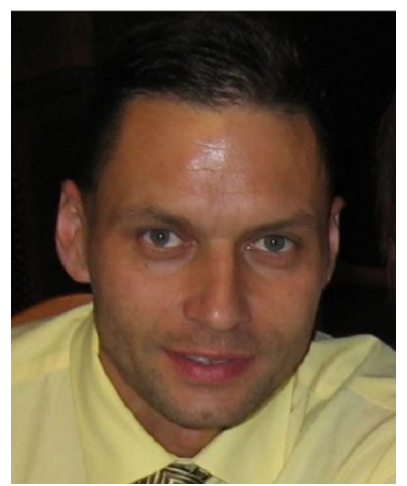

Richard Pospíšil Assoc. prof., graduated from the Faculty of Business and Economics at Mendelu University in Brno, the Czech Republic, where he habilitated in Economics and Management in 2009. At present he works at the Department of Applied Economics at Palacky University in Olomouc. His areas of expertise includes economic policy, public finance and monetary policy, as well. In 2019 he published the monograph Economics of Public Budgets in the press house Professional Publishing, he also publishes in scientific and professional press. Till now he has published 20 scientific articles at the Web of Science journals which have been 40 times cited. 